\title{
The Effect of School Design on Student Performance
}

\author{
Mohsen Ghasemi Ariani ${ }^{1,2} \&$ Fatemeh Mirdad ${ }^{2}$ \\ ${ }^{1}$ Department of English, Science and Research Branch, IAU, Neyshabur, Iran \\ ${ }^{2}$ Department of Architecture, IAU, Mashhad, Iran \\ Correspondence: Fatemeh Mirdad, Department of Architecture, IAU, Mashhad, Iran. Tel: 98-936-574-0839. \\ E-mail: fatemehmirdad@gmail.com
}

Received: May 14, 2015 Accepted: July 20, 2015 Online Published: December 29, 2015

doi:10.5539/ies.v9n1p175 URL: http://dx.doi.org/10.5539/ies.v9n1p175

\begin{abstract}
The present study aims at exploring the influence of school design on student performance. The participants consisted of 150 students who studied at two Iranian public school and private school in Mashhad City. School Design and Planning Laboratory (SDPL) model of Georgia University (and Tanner (2009)) was used as an appraisal indicator of school design and some of its design characteristics such as unrestricted and functional views, indoor and outdoor spaces, and natural life were explained to students. In addition, student performance, defined by the average of their final achievement scores, was compared to measures of school environmental characteristics. To this end, design characteristics of these schools and students' performances have been studied. Quantitative data, subjected to a set of descriptive statistics, showed that school design was a strong factor for students of private school. In fact, the finding indicated that characteristics of physical learning space and deign of private school had fundamental effects on student performance. That is, learning space as a strong component can motivate students to study and progress.
\end{abstract}

Keywords: school design, student performance, design characteristics

\section{Introduction}

Studies about student performance and physical learning spaces indicate that the physical spaces have influence on student performance. According to the researches, the spaces and environments that students spend a good deal of their time learning have effect on how well they learn (e.g., Earthman, 2004). Physical features of learning spaces can stimulate emotions, create a sense of security, and prepare the students to learn. Gifford's (2002) analysis indicates that interior architecture and internal features of learning spaces can help students focus their attention on studying or prevent them from giving full attention to learning (Yeung, Craven, \& Kaur, 2014). Desirable designs consist of having unmatched entrance areas, quiet private and public spaces that improve a sense of mutual support and unity with special attention to the color diversity (McGregor, 2004). Yeoman (2012) demonstrates that design characteristics such as poor acoustics, poor ventilation, insufficient lighting, and chronic noise exposure undermine learning. Today, school planners should create learning environments that motivate students and support learning and teaching. In fact, physical environments should not be only functional, they should provide tranquilizing spaces such as sound architecture and unique design. Although school designs and physical learning environment are important, designing and planning educational spaces are controversial issues in Iran. On the one hand, there are professional school planners who are good at planning. On the other hand, there are a few schools and buildings based on world standards. Besides, these school designs can have influence on student performance and motivation. Learning creates in a special space and planners should care about the learning space in order to foster educational level and delineate a sound architecture. In fact, creating the optimal learning and teaching spaces are an art that improves student performance and motivation. Effective educational spaces allow students to work collaboratively with each other and to improve their cognitive functioning. As well, it is the result of collaboration between school planners and school officials. New schools and learning environments should incorporate new technologies and connect learning process to the outside world. That is, students should feel that their environment, education and training tools are interconnected exactly. When physical learning spaces meet environmental and educational criteria, students and teachers will be inspired to perform better. In general, great efforts should be made to stimulate student reflection, to promote individual learning, and to offer learning opportunities. 


\section{Review of Literature}

There are some researches that scrutinize the influence of the physical learning and teaching spaces such as acoustics climate, noise, air quality, spatial density, and seating on students' performance and attendance (e.g., Earthman, 2004; Keep, 2002; Lackney \& Jacobs; 2004; McNamara \& Waugh 1993; Sundstrom, 1987; Weinstein, 1979). Fisher (2005) pays serious attention to effective learning environments and their impacts on education. In fact, the topics of physical learning and teaching spaces and student performance have been the centers of attractions. As well, technology as a powerful instrument interacts with leaning spaces (Lomas \& Oblinger, 2006; Montgomery, 2008; Oblinger, 2006). The study of learning and teaching spaces and the influence of formal spaces on student performance have centered on considerable researches. The researches indicate that physical learning spaces can foster students' abilities and improve their performances. Therefore, combining redesigns of learning and teaching spaces with students' interest can lead to students' performance and outcome (Brooks, 2011). Baker and Bernstein (2012) also state that physical learning spaces that are remodeled, collaborative and student-centered facilitate learning processes. Earthman and Lemasters (2011) conducted a study to examine whether physical learning spaces encourage students. This study reveals that students perform better when proper tools such as efficient environmental spaces and inviting learning places are provided. Daisey, Angell, and Apte (2003), Lyons (2001), and Schneider (2002) note that environmental conditions in school facilities affect student performance. According to Schneider (2002), healthy and comfortable learning spaces are strong factors for successful learning. Lyons's (2001) analysis shows that temperature, heating and air quality, lighting and acoustics are strong components that hinder or enhance student performance. Research has proven that school buildings and designs can boost student morale and performance. In fact, student performance is tied up with school design and equitable access to learning tools and spaces enable students to share best practices (Zubrzycki, 2013). Therefore, it is urgent to raise public awareness of school design and student performance.

The present research examines the influence of school design on student performance in Iran. In line with this purpose, it was aimed to see whether the physical learning spaces can support learning or not.

This study sets out to answer one (research) question?

Is there any significant relationship between school design and student performance?

\section{Method}

\subsection{Participants}

The participants of this study were 150 Iranian students (first grade) from two public and private high schools in Mashhad city.

\subsection{Instrument}

Interviews were carried out with the students to find out how they are familiar with explained design characteristics. In fact, the interview was based on Planning Laboratory (SDPL) model of Georgia University and Tranner (2009) that is presented in the appendix. As well, students took final exams and their performances were compared.

\subsection{Data Collection Procedure}

The qualitative aspect of this research is going to consider the influence of learning and teaching space on student performance. To this end, design characteristics were grouped in terms of three sets of patterns such as movement and circulation, day lighting, and views (Tanner, 2009). And the interview was carried out and recorded. In fact, the patterns were translated to Persian language and the interview was done in Persian. The instrument section tries to evaluate school design and consists of the 13 items. This instrument contains a ten-point Likert scale and the items are scored from zero to ten. A zero score or blank item shows the lowest degree of presence in physical space of school. On the other hand, a ten score indicates the highest degree (the attitudes of the students towards design patterns). Total score of the school was interpreted into four rankings such as superior, good, adequate, and inadequate. To accomplish the purpose of this study, the average of final achievement scores of the students in public and private schools are analyzed. To describe the interaction between school design (public and private) and students' developmental level, the quantitative data are subjected to descriptive analyses. These comparisons pave the way for conclusion in terms of educational progress and psychological impact of space.

\section{Results}

The present study explores the influence of school design on student performance in Mashhad city, Iran. Although Mashhad is one of big cities in Iran, school structure and educational spaces are not equipped well. 
Analysis of the data shows that design classifications affect students' performance of private school more. More importantly, the students of public school paid little attention to physical environment. The findings also reveal that circulation and movement have a significant influence on students of private school, while the other two patterns, views and day lighting, show statistically less effects among students of private school. Table 1 indicates the design ratings based on SDPL model for schools. They range from inadequate level to superior level.

Table1. Design scale based on SDPL model

\begin{tabular}{ll}
\hline Collected points for the items & Design ranking for the schools \\
\hline $117-130$ Points & Superior \\
$104-116$ Points & Good \\
$91-103$ Points & Adequate \\
$<90$ & Inadequate \\
\hline
\end{tabular}

Public and private school designs were measured and scored. Table 2 shows scores for design characteristics of learning space.

Table 2. Scores for three classifications

\begin{tabular}{ll}
\hline School classifications & Scores for three \\
\hline Public & 91 \\
Private & 105 \\
\hline
\end{tabular}

The average scores (Table 2) for three classifications indicate that students of public school pay less attention to physical learning environment and school design. More importantly, all of the students did not find their high schools design superior. It shows that students agree on one thing and that one is school design. In fact, school design is the third angel of an educational triangle including teacher, material, and architecture. School designers not only build educational spaces but also become involved in shaping the students and their worlds.

Student performance has been studied. Table 3 indicates average scores of the public and private schools.

Table 3. Average scores

\begin{tabular}{ll}
\hline School & Average of Final Scores \\
\hline Public & $16($ out of 20$)$ \\
Private & $17.5($ out of 20$)$ \\
\hline
\end{tabular}

The findings (Table 3) demonstrate that the students in private school did better than the students of public school. Scores range from zero to twenty in Iranian educational system. To this end, the more the score is near to twenty, the more the student is clever.

Environmental characteristics of public school and private school are compared to student performance. Table 4 shows the influence of school design on student performance. 
Table 4. Effects of school design on student performance

\begin{tabular}{lll}
\hline Design Classification & \multicolumn{2}{c}{ Student Performance Sum of Squares } \\
\hline (Test of Effects) & Public Private & Public Private \\
Movement and Circulation & Final exam & 392492.54 \\
Day Light & Final exam & 199200 \\
Views & Final exam & 255.24301 .12 \\
\hline
\end{tabular}

Table 4 shows that school design interacts with student performance. Although physical learning spaces are important to students, they are more important among students of private school. This table indicates that students pay more attention to movement and circulations. In fact, outdoor spaces absorb students. On the other hand, sources of light receive less attention.

This study places emphasis on importance of school design on student performance. As such, school planners can bring comfort to educational spaces with the aid of technology and sound architecture. In fact, students deserve best learning spaces and technologies. Students should not be deprived of learning and appropriate learning environments. Education consists of methodology and tools. Technology, learning space, and materials are learning and teaching tools. Students are not containers of knowledge and they need necessary tools to learn. According to this study, indoor and outdoor spaces can absorb students and affect their performances. Teacher, learning space and school planner can shape students.

\section{Discussion}

The purpose research tries to study and investigates the effect of school design on student performance. Schneider (2002) rates physical spaces as likely to affect student behavior and performance. That is, designing effective learning environments is really an important case to support constructive learning and performance. The findings indicate that school design has influence on student performance and the article concludes by suggesting that school planners and teachers should work more closely with each other in terms of better environment and better education and that not only should school planners and architectures improve their understanding of learning and teaching issues but also the policy makers should benefit from the hindsight experiences of school planners and teachers as consultants. The present study also suggests that the future of physical learning spaces will be promising if planners and architectures work on educational issues, and also on acquiring knowledge and qualifications in other related disciplines in order to better prepare them for paying attention to physical learning environments. To motivate students, some factors such as teachers, materials and curricula play important roles. Another factor that should be considered is school design and learning environment. Iranian school planners should pay more attention to this psychological criterion instead of decreasing their expenses. Schools are the only places that students spend most of their times, so learning space, place and time are worth in gold. And school design and technology are powerful instruments that can affect conscious and subconscious minds and shape the students. In general, human beings are looking for the beauty and the beauty can be an incomparable building or a perfect teaching. Entering an educational space should create a feeling of great eagerness about learning and increase creative ways of thinking. Iranian school planners and policy makers should aim to consider the educational needs of students such as appropriate facilities and physical designs, information and communications technologies, and proper learning spaces. Based on this study, there are some factors that make a good school environment. Schools should offer effective indoor and outdoor qualities to motivate their students. Learning in appropriate physical spaces and proper educational spaces instills a sense of pride and progress. Although school designs require some investment, these costs can create creativity, talent, and development in the society. And learning environments should incorporate new technologies and connect learning process to the outside world. To this end, design characteristics of learning space are really important and schools that adhere well to effective environmental and educational spaces can expect impressive benefits in student performance.

The findings of this study indicate that characteristics of physical learning space and deign of school affect student performance. That is, learning space as a strong component can motivate students to make progress. Consequently, learning depends on sound architecture and appropriate learning spaces. And the main implication of this study is that indoor and outdoor learning spaces such as comfortable paths and walkways, light sources, school's main building, and natural features of a landscape have impact on learning. In fact, these factors enable students and teachers to improve learning and teaching processes. 


\section{References}

Baker, L., \& Bernstein, H. (2012). The impact of school buildings on student health and performance: A call for research. The Center for Green Schools and McGraw-Hill Research Foundation. Retrieved from http://mcgraw-hillresearchfoundation.org/wp-content/uploads/2012/02/GreenSchoolsWP-2012.pdf

Brooks, D. C. (2011). Space matters: The impact of formal learning environments on student learning. British Journal of Educational Technology, 42(5), 719-726. http://dx.doi.org/10.1111/j.1467-8535.2010.01098.x

Daisey, J. M., Angell, W. J., \& Apte, M. G. (2003). Indoor air quality, ventilation and health symptoms in schools: An analysis of existing information. Indoor Air, 13, 53-64. http://dx.doi.org/10.1034/j.1600-0668.2003.00153.x

Earthman, G. I. (2004). Prioritization of 31 criteria for school building adequacy. Baltimore: American Civil Liberties Union Foundation of Maryland. Retrieved from http://www.schoolfunding.info./policy/facilities/ ACLUfacilities-report1-04.pdf

Earthman, G., \& Lemasters, L. (2011). The influence of school building conditions on students and teachers: A theory-based research program. The ACEF Journal, 1(1), 15-36.

Fisher, K. (2005). Research into identifying effective learning environments, evaluating quality in educational facilities, OECD/PEB. Retrieved from http:// www.oecd.org/dataoecd/26/7/37905387.pdf

Keep, G. (2002). Building that teach. The Educational Facilities planner, 37(2).

Lackney J. A., \& Jacobs, P. J. (2004). Teachers as playmakers: Investigating teachers use of the physical learning environment in instructional design. Research report. Retrieved from tttp://www.eric.ed.gov/PDFS/ED463645.pdf

Lomas, C., \& Oblinger, D. (2006). Student practices and their impact on learning spaces. In D. Oblinger (Ed.), Learning spaces (pp. 5.1-5.11). Washington, DC: EDUCAUSE.

Lyons, J. (2001). Do school facilities really impact a child's education? In Issue Trak: A CEFPI Brief on Educational Facility Issues. Scottsdale, AZ: Council of Educational Facility Planners International.

McGregor, J. (2004). Specialty and the place of materials in schools. Pedagogy, Culture and Society, 12(3), 347-372. http://dx.doi.org/10.1080/14681360400200207

McNamara, D., \& Waugh, D. (1993). Classroom organization. School Organization, 13(1), 41-50. http://dx.doi.org/10.1080/0260136930130104

Montgomery, T. (2008). Space matters: Experiences of managing static formal learning spaces. Active Learning in Higher Education, 9, 122-138. http://dx.doi.org/10.1177/1469787408090839

Oblinger, D. (2006). Space as a change agent. In D. Oblinger (Ed.), Learning spaces (pp. 1.1-1.4). Washington, DC: EDUCAUSE.

Schneider, M. (2002). Do school facilities affect academic outcomes? Washington, DC: National Clearinghouse for Educational Facilities.

Sundstrom. E. (1987).Work environments: Offices and factories. In D. Stockol, \& L. Altman (Eds), Handbook of environmental psychology (p. 751, pp. 733-782). NY: John Whiley \& Sons.

Tanner, C. K. (2009). Effects of school design on student outcomes. Journal of Educational Administration, 47(3), 381-399. http://dx.doi.org/10.1108/09578230910955809

Weinstein. (1979).The physical environment of the school: A review of the research. Review of Educational Journal, 49(4), 577-610.

Yeoman, B. (2012). Special report: Rebuilding America's schools. Parade Magazine. Retrieved from http://www.parade.com/news/2012/08/12-rebuilding-americas-schools.html

Yeung, A. S., Craven, R. G., \& Kaur, G. (2014). Teachers' self-concept and valuing of learning: Relations with teaching approaches and beliefs about students. Asia-Pacific Journal of Teacher Education, 42(3), 305-320. http://dx.doi.org/10.1080/1359866X.2014.905670

Zubrzycki, J. (2013). Schools' design can play role in safety, student engagement. Education Week, 32(16), 32. Retrieved January 17, 2013, from http://www.edweek.org/ew/articles/2013/01/10/16physical.h32.html?tkn= LYYFu5rSTJW8a 


\section{Appendix}

Table: Measure of design scale (SDPL model of Georgia University and Tranner (2009))

Instructions: Please mark the items (design patterns) from 0 to 10. Design consists of the way the school building (outdoor space and indoor space) is made. Each scale evaluates the learning space of the school and satisfaction ratings.

Type of School: (Public or private) Score:

Movement and Circulation

1. Comfortable pathways and indoor passages that let students move and pass through them.

Ambiguous Clear

012345678910

2. Outdoor paths and walkways that make a connection between main spaces and areas.

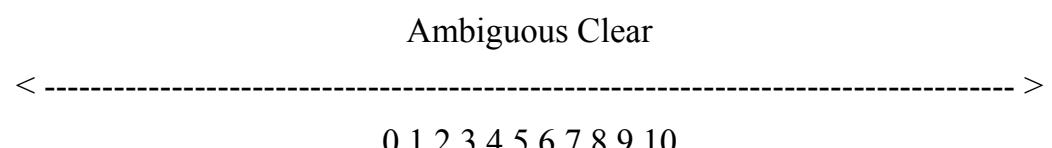

012345678910

3. Dining area that provides physical ease and adequate lighting.

Poor Excellent

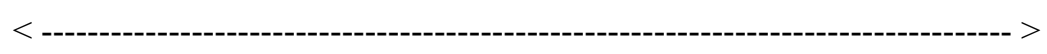

012345678910

4. Auditorium that is invitingly comfortable



012345678910

5. School's main building as a reference area links paths and other buildings.

Obscure Obvious

012345678910

6. Outdoor environment and learning space are surrounded by trees, walkway, fence, and buildings.

Non-existent Plentiful



012345678910

Views

7. Doors and windows allow students to see outside the classroom easily (functional views).

Inadequate Adequate

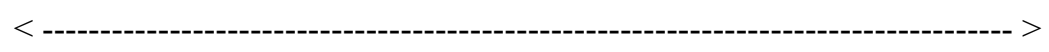

012345678910

8. Windows and doors in use enable students to look out and to pass through without preventions such as screen, veil, curtain, and lock (Unrestricted Views).

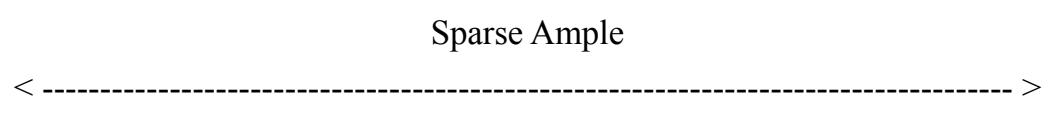

012345678910

9. All the natural features of a landscape, scenery, and views that overlook life and affect students.

None Numerous 


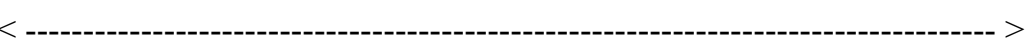

012345678910

10. Green areas and spaces such as gardens, trees and grass in the near distance and close to the learning space.

Non-existent Plentiful

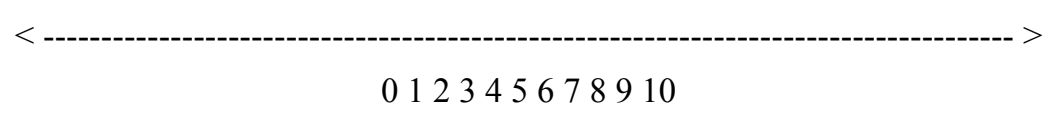

11. Vivid outlook of outdoor and indoor areas such as fountains, mountains, and gardens.

Sparse Ample

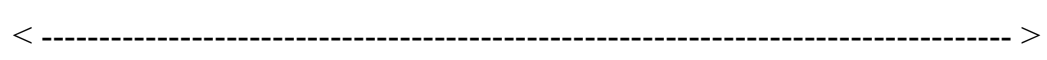

012345678910

Day Lighting

12. Physical learning space is equipped with natural and artificial lights (sources of light).

Poor Excellent

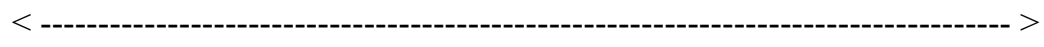

012345678910

13. Classrooms are provided with different light sources such as borrowed light, reflected light, and artificial light.

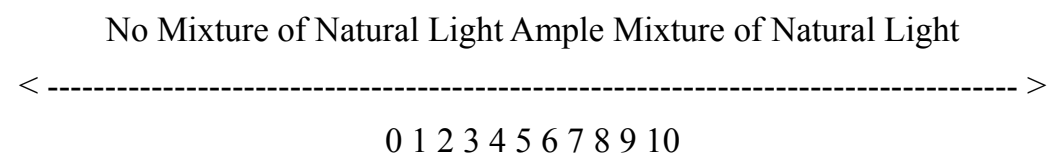

\section{Copyrights}

Copyright for this article is retained by the author(s), with first publication rights granted to the journal.

This is an open-access article distributed under the terms and conditions of the Creative Commons Attribution license (http://creativecommons.org/licenses/by/3.0/). 